NAGY EMőKE*

\title{
SZENT ANNA KULTUSZÁNAK JEGYEI A TELEKI-, KAZINCZY- ÉS ÉRDY-KÓDEX ALAPJÁN"
}

\author{
Kulcsszavak: kultusz, kódex, Szent Anna, legenda, ferences rend
}

Szent Anna ${ }^{1}$ személye körül sok vita folyt, amit részben apokrif történetének, részben a Mária fogantatása körüli teológiai kérdéseknek tulajdoníthatunk. A fennmaradt szövegemlékek alapján, úgy tűnik, hogy a késő középkorban leginkább a ferencesek terjesztették a szent kultuszát. Többnyire ferences környezetben írt prédikációk és legendák maradtak fenn a késő középkori Magyarországról. A tizenötödik század végén két híres magyar obszerváns ferences prédikátor, Temesvári Pelbárt ${ }^{2}$ és Laskai Osvát ${ }^{3}$ sermo-gyüjteményeiben találunk több, Szent Annáról szóló prédikációt.

* Nagy Emőke: PhD hallgató, ELTE, Bp. - BBTE, Kolozsvár

* E tanulmány angol nyelvú változata megjelent a Colloquia hasábjain. NAGy Emőke: Motherhood and Sanctity in the Cult of Saint Anne: The Reception of the Saint's Legend Based on her Earliest Sources from Medieval Hungary, the Teleki, Kazinczy, and Érdy Codices. Colloquia XVI(2009): 22-44. A Teleki-kódex Anna legendáját magiszteri dolgozatomban elemeztem: The Human Trinity and Christ Human Genealogy in Late Medieval Hungary. Saint Anne's Iconography and Textual Sources. Magiszteri dolgozat, kézirat. Középkor-tudományi tanszék. Közép-Európai Egyetem. Budapest. Köszönet illeti a budapesti Közép-Európai Egyetemet a szakdolgozat megírásához nyújtott segítségért. Továbbá ezúton megköszönném a szakvezetőmnek, KLANiczAY Gábornak (CEU-ELTE, Budapest) a szakmai segítségét. Emellett külön köszönet illeti GÁвоR Csillát, Maria CRĂcıunt és Carmen FLOREÁt a gyümölcsöző beszélgetésekért.

1 Alaptanulmányok Szent Anna kultuszára vonatkozóan: Beda Kleinschmidt: Die Heilige Anna: Ihre Verehrung in Geschichte, Kunst und Volkstum. Düsseldorf 1930; Dominique Costa: Sainte Anne. Nantes, 1966; Paul-Victor Charland: Le culte de Sainte Anne en Occident, second période: De 1400 environs à nos jours. Quebec, 1921. Új megközelítések, amit antropológiai, művészettörténeti, kultúrtönténeti vagy irodalmi elemzése a forrásoknak jellemez, a következők: Interpreting Cultural Symbols: Saint Anne in Late Medieval Society. Szerk. Kathleen Ashley-Pamela Sheingorn. Athens 1990; Ton Brandenbarg: Saint Anne: A Holy Grandmother and Her Children = Sanctity and Motherhood: Essays on Holy Mothers in the Middle Ages. Szerk. Anneke B. Mulder-Bakker. New York 1995.31-65; Uó: St. Anne and Her Family: The Veneration of St. Anne in Connection with Concepts of Marriage and the Family in the Early Modern Period = Saints and She-Devils: Images of Women in the Fifteenth and Sixteenth Centuries. Szerk. Lène Dresen-Coenders. London 1987.101-127; Angelika Dörfler-Dierken: Die Verehrung der heiligen Anna in Spätmittelalter und früher Neuzeit. Göttingen 1992; Uő: Vorreformatorische Bruderschaften der hl. Anna. Heidelberg 1992; Virginia Nixon: Mary's Mother: Saint Anne in Late Medieval Europe. Pennsylvania 2004. 1-55.

2 Pelbartus De Themeswar: Pomerium de sanctis II. [pars aestivalis]. Augsburg, 1502, 36., 37., 38. sermók. Jelen tanulmányhoz a kolozsvári Lucian Blaga Központi Egyetemi Könyvtár Kézirattárában megtalálható BMV 41 jelzetű kiadást használtam.

3 Osvaldus De Lasкo: Sermones de sanctis Biga salutis intitulati. Hagenau, 1499. 62., 63. sermók. A budapesti Országos Széchényi Könyvtár Inc. 1030 jelzetű példányát használtam. 
Jelen tanulmány a szent legendáin keresztül arra keresi a választ, hogy milyen üzenete lehetett az Anna-életrajzoknak bizonyos társadalmi csoportok számára, akiknek e legendák íródtak. Ahhoz, hogy e kérdést megválaszoljuk, figyelembe kell vennünk, hogy a szent kultusza igen vitatott volt a középkor folyamán. E viták alapját pedig éppen a szent legendái képezték. Erre vonatkozó, kultúrtörténeti tanulmány még nem született magyar vonatkozásban. Mostanáig a legendák filológiai, forrástörténeti elemzésére törekedtek a kutatók. ${ }^{4}$

\section{A KULTUSZ VITATOTT ELEMEI: SZENT ANNA APOKRIF LEGENDÁI}

A Biblia egyáltalán nem említi Mária szüleit, a szent életéről, legendájáról apokrif iratokból van tudomásunk. Az apokrif történet, miszerint Anna, meddősége ellenére idős korában, isteni kegyelem révén részesül gyermekáldásban, az 5-6. századtól kezdődően kezdett el terjedni Nyugaton.

A szent életét Nyugaton a Szent Jakab protoevangéliuma (Kr. u. 2) latin fordítása, az ún. Pseudo-Máté evangéliuma/Liber de Ortu Beatae Mariae et Infantia Salvatoris ${ }^{5}$ terjesztette (Kr. u. 550-700) és az ebből származó munkák, amelyek közül a legfontosabb a De nativitatae sanctae Mariae ${ }^{6}$ más nevén Mária születése evangélium. A Mária és szülei élettörténetét népszerűsítő evangélium a karoling korszak idején terjedt el Nyugaton, és az ebből származó szövegek száma jelentősen megnőtt az Ottók uralkodása idején. Az első adatok az Anna-kultuszra nézve a keleti Szűz Mária ünnepek elterejedésével vannak összefüggésben. Liturgikus emlékek csupán elszórtan vannak jelen a 12. század előtt Nyugaton. ${ }^{7}$

A Mária-kultusszal szoros összefüggésben, Szent Anna kultuszát a 12. században meghatározták a szeplőtelen fogantatás tana kapcsán kialakuló teológiai viták, illetve hatással volt rá az ugyancsak a 12. században elterjedt, a nyugati kereszténységben megszületett ún. trinubium legenda.

4 Katona Lajos: A Teleki-kódex legendái. Értekezések a nyelv- és széptudományok köréből XVIII (1904). 1-30; Horváth János: A magyar irodalmi müveltség kezdetei: Szent Istvántól Mohácsig. Budapest 1931. 214-215; Veres Anna: Szent Anna alakja a Jakab-féle ösevangéliumban és három kódexünkben. Plaustrum seculi III(2005): http://sermones.elte.hu/?az=337tan_plaus_veresanna (letöltve 2009. április 30.).

5 Evangelia apocrypha: Adbibitis plurimis codicibus graecis et latinis maximam partem nun primum sonsultis atque indeditorium copia insiguibus. Szerk. Constantinus Tischendorf. Leipzig 1876. 101140; Los Evangelios Apocrifos: Collección de textos griegos y latinos, versión critica, estudios introductorios, comentarios e ilustrationes. Szerk. Aurelio De Santos Otero. Madrid 1956. 189-258; BоLlóк János: Pszeudo-Máthé evangéliuma = Csodás evangéliumok.. Szerk. Adamiк Tamás. Ford. Adamiк Tamás, Bollók János. Budapest, 1996. 47-60.

6 A szöveget tévesen Szent Jeromosnak tulajdonították: De nativitate sanctae Mariae = Patrologiae Cursus Completus: Series Latina (a továbbiakban PL). Szerk. Jacques-Paul Migne. 221 kötet. Paris, 1844-1864. 30 kötet. cols. 297-305; Nixon: Mary's Mother. 166; Kathleen Ashley-Pamela SheIngorn: Introduction = Interpreting Cultural Symbols: Saint Anne in Late Medieval Society. Szerk. Kathleen Ashley-Pamela Sheingorn. Athens 1990. 10.

7 Kleinschmidt: Die Heilige Anna. 6-75; Ashley-Sheingorn: Introduction. 1-69; Brandenbarg: Saint Anne, 31-65; Uő: St. Anne and Her Family. 101-127; Nixon: Mary's Mother, 1-55. 
A teológusok a Mária szeplőtelen megfoganása körüli vita során nem lelkének szeplőtelenségét vonták kétségbe, hanem testének szeplőtelen voltát; mikor mentesült az eredeti bűntől? A következő lehetséges magyarázatok szolgáltak válaszul az egyháznagyok részéről: az angyali üdvözlet pillanatában - amikor hírül kapja Jézus megszületését, Anna méhében vagy még előtte, megfoganásakor. ${ }^{8}$

Az ún. ősapokrif irodalom, Szent Jakab protoevangéliuma és Pseudo-Máté evangéliuma, nem foglalta magában Anna három házasságának történetét. A Szent Anna három házasságáról szóló legenda eredete nem ismert pontosan. Auxerre-i Haymo bibliakommentátor jegyezte le a legendát a 9. században. ${ }^{9}$ A szerző a Jézus testvéreire vonatkozó újtestamentumi utalást magyarázva arra a következtetésre jutott, hogy Annának, Szűz Mária édesanyjának, három Mária nevű lánya volt, akik különböző házasságokból születtek, és az ő fiaik lennének valójában Jézus testvérei. A zsidó törvény értelmében az első férj halála után az elhunyt férj testvéreinek kötelessége az özvegyet feleségül venni, biztosítani jövőjét. Anna Joachim halála után férjhez megy Kleofáshoz, majd az ő halála után a harmadik testvérhez, Salomáshoz. A második házasságból született Mária Kleofás Alpheusszal házasodik össze és életet ad ifj. Jakabnak, Igaz Józsefnek, Simonnak és Júdásnak. Mária Salomás Zebedeushoz megy férjhez és megszüli id. Jakabot és János Evangélistát. ${ }^{10}$

A késő középkorban megsokszorozódtak azon értekezések, melyek Anna három házasságának tételét támadták. Aquinói Szent Tamás (1225 k.-1274) írásaiban mindkét nézetet támadta, mind a szeplőtelen fogantatás tanát, mind a trinubium legendát. Ugyanakkor kifejtette Mária megszentelődésének történetét. Eszerint jóllehet Mária bűnben fogant, az emberiség törvényeinek megfelelően, megszabadult a tisztátalanságtól, akkor, amikor megszentelt lelke testéhez kapcsolódott anyja, Anna méhében. ${ }^{11}$ E nézetet, miszerint Mária Anna méhében nyerte el a megtisztulást, vallották a későbbiekben, a késő középkor folyamán, a domonkosok (makulisták). ${ }^{12}$

A ferencesek (immakulisták) ezzel szemben azt vallották, hogy Mária az eredeti bűn nélkül, azaz szexuális vágy nélkül fogant. Vagyis Isten kivételt tett Mária esetében. A Mária megszentelődése és megváltása közötti különbséget az oxfordi ferences iskola tisztázta (Ware

8 Charles Journet: Scripture and the Immaculate Conception = The Dogma of the Immaculate Conception: History and Significance. Szerk. Edward Dennis O'connor. Paris: University of Notre Dame Press, 1958. 1-51, 44; Carlo Balić: The Mediaeval Controversy over the Immaculate Conception = The Dogma of the Immaculate Conception. Szerk. O'Connor. 174.

9 Ashley-Sheingorn: Introduction. 11-17; Brandenbarg: Saint Anne. 41-42; Nixon: Mary's Mother, 13-16.

10 Haymo Of Auxerre: Historiae sacrae epitome = PL, 118 kötet, cols. 823-824. A szöveget előzőleg Halberstadti Haymónak tulajdonították. Lásd Baudouin De Gaiffier: Le Trinubium Annae, Analecta Bollandiana XC (1972). 289-298; ASHLEY-SHEINGORN: Introduction. 59; Nixon: Mary's Mother, 168.

11 Thomas Aquinas: Super Epistolam ad Galatas lectura, lectio 5 = Commento al Corpus Paulinum (Expositio et lectura super epistolas Pauli apostoli). Szerk. Battista Mondin. 3 kötet: Seconda lettera ai Corinzi, Lettera ai Galati. Bologna. 2006. 563-569; Uő: Summa Theologiae IIIa, q. 27. Milan 1988. $14-15$.

12 Ashley-Sheingorn: Introduction. 13-17; Nixon: Mary's Mother. 13-16. 
Vilmos, Duns Scotus János). ${ }^{13}$ Duns Scotus (1265/66-1308) azt tanította, hogy Mária mentes volt az eredeti bűntől megszületésétől kezdődően, egészen az emberiség kereszten való megváltásáig. Jézus megváltó cselekedete előre mentesítette őt minden bủn alól. ${ }^{14}$

Anna meddősége, miszerint idős korában isteni kegyelem lévén születik meg első Mária lánya, nehezen volt egyeztethető a trinubium legenda által terjesztett három házassággal. E legenda vitatott volta ellenére Pszeudo-Máté későbbi változataiba belekerült. Egyike ezen késői változatoknak, a Mária születése evangélium ${ }^{15}$ szolgált alapul Iacobus de Voragine Arany legendájának. ${ }^{16}$ Ezen keresztül a legenda a késő középkori prédikációs irodalom részévé vált. Emellett a későközépkori hagiográfiai irodalom terjesztette Anna három házasságának történetét, ami elsősorban német nyelvterületen terjedt igen nagy számban a 15-16. században. ${ }^{17}$

Az Anna-életrajzok vitatott volta miatt, ill. a hagiográfia műfaji sajátosságából kiindulva, miszerint egy adott nézőpont kifejezője, több antropológiai megközelítésű elemzés is született a nyugat-európai Szent Anna-kutatók körében. Ton Brandenbarg a német nyelvterületen terjedő Anna-legendák esetében azt vizsgálta, milyen mértékig tükrözhetnek házassághoz, háztartáshoz kötődő nézeteket, milyen közönségnek szóltak. ${ }^{18}$

\section{SZENT ANNA-LEGENDÁK A KÉSŐ KÖZÉPKORI MAGYARORSZÁGON}

Ugyan Szent Anna 14. századi, magyarországi kultuszának a terjesztésében a pálosok, Ágoston-rendiek, klarisszák is kitűnnek, a kultusz késő középkori terjesztése, úgy tűnik, a koldulórend, elsősorban a ferenceseknek köszönhető a fennmaradt szövegemlékek alapján.

Amint már korábban említettem, a jobbára ferences közegből származó legendákkal csupán forrástörténeti szempontból foglalkoztak kutatások, eszmetörténeti irányba mutató kutatás, ami a késő középkori devóció szempontjából elemezze a legendákat, nem történt meg mostanáig. ${ }^{19}$

13 Gulielmi Guarra - Ioannes Duns Scotus-Petrus Aureolus: Quaestiones disputatae de immaculata conceptione Beatae Mariae Virginis. Quaracchi 1904. 1-22; JouRnet: Scripture and the Immaculate Conception. 46; Balić: The Mediaeval Controversy over the Immaculate Conception. 202-212.

14 Ioanes Duns Scotus: Opera Omnia, 20 kötet: Lectura in librum tertium sententiarum, dist. 1-17. Vatican City 2003, d. 3, q. 1. 119-138; BaLić: The Mediaeval Controversy Over the Immaculate Conception. 204-212; Marina Warner: Alone of All Her Sex: The Myth and the Cult of the Virgin Mary. 2. kiadás. New York 1983.242.

15 De nativitatae sanctae Mariae = PL, 30. kötet, cols. 297-305.

16 Iacopo Da Varazze: Legenda Aurea. Szerk. Giovanni Paolo Maggioni. 1-2. Florence 1998. 2. kötet, 900-917; Branden BARg: Saint Anne. 41-42.

17 Angelika Dörfler-Dierken összegyüjtötte és elemezte a német nyelvterületen megjelent Anna-legendákat a késő középkorra nézve. Ennek alapján arra a következtetésre jutott, hogy a késő középkori hagiográfiai munkák Rudolph Agricola Szent Anna versének a hatását mutatják (1484-ben adták ki, Deventer, Strassburg, Basel), mint például Petrus Dorlandus Anna-legendája (Historia perpulchra de Anne sanctissima. Antwerp, ca. 1487). Lásd Dörfler-Dierken: Die Verehrung der heiligen Anna. 170-186.

18 Brandenbarg: Saint Anne. 31-65; Uő: St. Anne and Her Family. 101-127.

19 Katona: A Teleki-kódex legendái. 1-30; Honvát H: A magyar irodalmi müveltség kezdetei. 214-215; VEREs: Szent Anna alakja http://sermones.elte.hu/?az=337tan_plaus_veresanna (letöltve 2009 április 30$)$. 
Szent Anna legendája szabadolvasmányként szerepelt a kolostori irodalomban. A Marosvásárhelyen másolt Teleki-kódex ${ }^{20}$ Anna-legendája a legkorábbi és legteljesebb Anna-legenda. Marosvásárhely fontos ferences kulturális központ volt a középkorban. A Kazinczy-kódex ${ }^{21}$ Anna-legendája úgyszintén ferences közegben íródott. Mindkét kódexet a 16. század elején másolták, az Anna-legendák forrása az ún. Legenda sanctissimae matronae Annae, Anonymus ferences munkája, ami 1496-tól terjedt több kiadásban Nyugat-Európában. ${ }^{22}$

Az Érdy-kóde ${ }^{23}$ Anna-legendájának forrása az Arany Legenda vagy Temesvári Pelbárt Anna-prédikációja, aki a maga során az Anna-legendát vette alapul. A Karthauzi Névtelennek tulajdonított munka, ami a legteljesebb fennmaradt legenda- és prédikációgyújtemény, feltehetően tágabb közönségnek szólt, amire a kódex prológusában foglaltak alapján következtethetünk (lövöldi laikus testvérek, több rendbéli apácák). ${ }^{24}$

A célközönség és szerzőség figyelembevétele a téma antropológiai megközelítését teszi lehetővé. E megközelítés alapján a szent kultuszának különböző vonatkozásait értelmezhetjük: mit jelenthetett egy apáca, begina, laikus testvérek számára legendájának, csodájának olvasása? Továbbá ugyanezt a megközelítést teszi lehetővé a legendák tartalmi összevetése. Illetve kérdésfelvetésként azt kell megválaszolnunk: milyen modellt szolgáltatott a szent eme olvasóközönségnek?

\section{A TELEKI-KÓDEX ANNA-LEGENDÁJA}

A Teleki-kódexet egy ferences prédikátor (Sepsiszentgyörgyi Ferenc fráter) és valószínúleg több harmadszerzetbeli húgok/beginák másolták (1525-1531) Marosvásárhelyen (a kódex tartalmazza a harmadszerzetbeli húgok reguláját). ${ }^{25} \mathrm{~A}$ szerzőséget támasztják alá a régészeti, tör-

20 Teleki-kódex. Szerk. Volf György. Budapest 1884 (Nyelvemléktár 12) .1-149. A kritikai kiadása a kódexnek (Nyelvemléktár) tartalmazza a kódex eredeti lapszámozását. Jelen tanulmányban a kritikai kiadás lapszámozását és sorszámát használtam.

21 Kazinczy-kódex 1526-1541. A nyelvemlék hasonmása és betühú átirata bevezetéssel és jegyzetekkel. Szerk. Kovács Zsuzsa. Budapest 2003 (Régi magyar kódexek 28). 39-58. A kódex kritikai kiadása feltünteti a lapszélen a mú eredeti lapszámozását. Jelen tanulmányban a kritikai kiadás lapszámát és sorszámát használtam.

22 Anonymus Ferences: Legenda sanctissime matrone Anne genitricis Virginis Marie matris et Hiesu Cristi avie. Lipcse, 1497. http://tudigit.ulb.tu-darmstadt.de/show/inc-ii-236/0001 (letöltve 2011.05.11); Katona: A Teleki-kódex legendái. 1-30; HoRvát H: A magyar irodalmi müveltség kezdetei. 214-215.

23 Érdy-kódex. Szerk. Volf György. Budapest 1876 (Nyelvemléktár 5). 144-150. A kódex kritikai kiadása feltünteti a lapszélen a mú eredeti lapszámozását. Jelen tanulmányban a kritikai kiadás lapszámát és sorszámát használtam.

24 A Karthauzi Névtelen által írt latin nyelvű prológus az első ars poetica amiről tudomásunk van a magyar irodalomban. Az író megnevezi célját a kódex prológusában, miszerint azon különböző rendből származó laikus testvéreket és apácákat szeretné segíteni, akik nem tudnak latinul. Érdykódex, XXIII-XXIV; A Néma Barát megszólal. Válogatás a Karthauzi Névtelen beszédeiböl. Szerk. Madas Edit. Bp., 1985. 11-12.

25 Teleki-kódex. 400-401; Horváth János foglalkozik a szerzőséggel tanulmányában. Lásd HoRvÁtн: A magyar irodalmi müveltség kezdetei. 146. További munkák általánosabban fogalmaznak: 
téneti kutatások, miszerint a késő középkorban Marosvásárhely jelentős ferences kulturális központ volt, ahol ferences kolostor, valamint begina rendház múködött. ${ }^{26} \mathrm{~A}$ késő középkorban az ún. harmadszerzetbeli húgok/beginák hasonló szabályzat alapján éltek, akárcsak a klarisszák. ${ }^{27}$ Emiatt ugyanazon olvasóközönségnek számítanak az Anna-legendák szempontjából.

Milyen üzenete lehetett tehát az Anna-legendáknak kolostori környezetben?

A Teleki-kódex Szent Anna-legendája (17 ún. könyvre van osztva) Mária-zsoltárok sorába ékelődik. A 15. század végi Anna-legendaváltozatoknak megfelelően a történet Anna édesanyja, Emerentia látomásának elmesélésével kezdődik, aki, habár apáca szeretett volna lenni, Karmel hegyi látomás hatására, miszerint szent utódai lesznek, lemondott a szerzetesi életéről és a házaséletet választotta.

„E megmutatott fa, látásra szépségös, a szíz szent Emerencia asszonnak fénylő tisztaságát példázza, és az ő szent szándékát mendenkoron az Istennek akaratjára mondja... az ô leányát, szent Anna asszont, ő tőle születendőt példázza, mely szent Anna asszontul, egy virág hozattatik, avagy születtetik, mely malaztal teljes leszön... az édes szíz Mária, örökkön örökké szeplőtelen marad meg, a virágtul kedig, a szíz Máriátul, az édességes gyömölcs, Istennek fia”. ${ }^{28}$

A második fejezet ${ }^{29}$ Anna gyerekkorát és példaadó életét mutatja be. A szerző megindokolja Anna első házasságát, miszerint Joachimhoz nem bujaságból fakadóan, hanem az emberiség törvényeinek engedelmeskedve ment férjhez. A történet kevés részlet kivételével ${ }^{30}$ megegyezik Pszeudo-Máté evangéliumában elmondottakkal; gyermektelen házasságukat, Joachim áldozatát a templomban, az angyali üdvözletet, a találkozást az Aranykapunál és Mária születését különböző fejezetekben részletezi a szerző (III-V) ${ }^{31}$.

A következő fejezetek (VI..$^{32}$ VII. ${ }^{33}$ ) Anna három házasságának történetét mutatják be. Joachim halála után a megözvegyült Anna férjhez megy elhunyt férje testvéréhez, Kleofáshoz,

MADAs Edit: Írás, könyv és könyvhasználat a középkori Magyarországon, 1000-1526 = A könyvkultúra Magyarországon, a kezdetektől 1800-ig. Szerk. MadAs Edit-MonoK István . Bp., 2003. 67.

26 Karácsonyi János : Szent Ferencz rendjének története Magyarországon 1711-ig. 1-2.. Bp., 19221923, 1 kötet. 203. 2. kötet. 114-116; Bonos Fortunát: Az erdélyi ferencrendiek. Kolozsvár 1927. 13-47; Soós Zoltán: The History of the Târgu Mureş Franciscan Friary. A Comparative Study of the Transylvanian Franciscans Architecture. Magiszteri dolgozat, kézirat. Középkor-tudományi Tanszék. Közép-Európai Egyetem. Bp. 2000. 15-28; John R. H. Moorman: Medieval Franciscan Houses. New York 1983 (Franciscan Institute Publications History Series 4). 290.

27 John R. H. Moorman: A History of the Franciscan Order from its Origins to the year 1517. Oxford 1968. Reprint. Oxford 1998. 560-568.

28 Teleki-kódex. 278/23-32. A kritikai kiadásra alapozva, átírtam az elemzett kódexbeli szöveget a mai helyesírási gyakorlatnak megfelelően. A kutatók által elfogadott módszert követtem, miszerint érthetőbbé kívántam tenni a szövegeket: e. g. c-k, ÿ - i, z-sz, n - ny stb. Ezúton meg szeretném köszönni GÁвов Csillának, hogy segített a szövegek átírásában.

29 Uo. 281-283.

30 Veres Anna tanulmányában összeveti tartalmilag a Jakab-féle ősevangéliumot (Pszeudo-Máté evangéliuma erre épül) a Teleki-, Kazinczy- és Érdy-kódex Anna-legendáival. Nem veszi figyelembe azonban a közvetlen forrását a Teleki- és Kazinczy-kódex Anna-legendáinak, az Anonymus Ferences által írt Legenda sanctissimae matronae Annae-t. Lásd Veres: Szent Anna alakja.

31 Teleki-kódex. 283-291.

32 Uo. 291-293.

33 Uo. 293-297. 
majd az ő halála után, a harmadik testvérhez, Salomáshoz. Jóllehet a zsidó törvény értelmében az özvegynek férjhez kell mennie az elhunyt férj testvéréhez, a legendában az eseményt az angyal híradása indokolja meg: Annának további két Mária lánya fog születni, akiknek utódai lesznek a jövendőbeli apostolok. A második férj halála után Anna Isten szolgálatába ajánlja magát, de ebbéli terve újra meghiúsul, az angyal intő szava miatt, miszerint további Mária nevű lánya fog születni, és ne szégyenkezzen amiatt, hogy újra házasságra lép.

A legenda szerzője, ill. másolója többszörösen kihangsúlyozza, hogy Anna nem csupán engedelmeskedik a zsidó törvényeknek, hanem különleges megtiszteltetésben van része, mivel isteni terv részévé válhat.

A legenda szerint Anna példaadóan neveli lányait: „az isteni tisztességöt a penitenciatartásnak gyakorlásába megtartani...”34, illetve: „a szentségös vén Tóbiásnak példájával tanítá az ő leányit az ô gyengeségös korokba, állapotokba Istent mendenöknek fölötte félniök, ájtatossággal imádkozniok...”35

Szent Anna jellemét - a bölcs anya képe mellett - a korabeli szentek körében is megtalálható példákkal egészíti ki a szerző: bűnbocsánat, éjszakai ima, önsanyargatás, böjt, szegények, betegek segítése (elsősorban a pestisben szenvedőkké): ${ }^{36}$

„...demaga bízék Istenbe, állhatatos vala, a parancsolatoknak megtartásiban, és imádságokba, éjjel, és nappal, gyakorlatossággal az éjeket könnyhullatásokkal költi vala el...némikoron testét öztöverítvén, bőjtöl vala, némikoron az szegényöknek kegyes szolgálatokat teszön vala...korokkal, betegökkel, és poklosokkal bánik vala, és megförözti vala őket...”. ${ }^{37}$

Anna leszármazottait, akárcsak Emerentia esetében, egy fa képében mutatja be a szerző:

„...e szent Anna asszon az ő annyjátul gyömölcsös termő gyökerétül, e szent Emerencia asszontul, három szőlő vesszőket... Máriákat hoza, teremte, szüle, e világra honnat egyiktül lőn, kiboltó, származó, édességös illatú virág, mely virág lőn, mend e teljes, elkárhozott emberi nemzetnek kegyes üdvözítteje, és a más két Máriáktul kedig, bimbók, virágok, levelek, ágak, és magok lőnek, melyek mend e teljes világot, kiboltó, származó, édes illatúvá teszik, mert lám a bizonság, tanubizonságot teszön, hogy az jó fa, gonosz gyömölcsöt nem tehet.”. ${ }^{38}$

34 Uo. 295/22-23.

35 Uo. 295/23-26.

36 Fontos munkák e témakörben: Michael E. Goodich: Vita perfecta: The Ideal of Sainthood in the Thirteenth Century. Stuttgart 1982; Caroline Walker Bynum: Holy Feast and Holy Fast: The Religious Significance of Food to Medieval Women. Berkeley 1987. 31-48; Jo Ann Mcnamara: The Need to Give: Suffering and Female Sanctity in the Middle Ages = Images of Sainthood in Medieval Europe. Szerk. Renate Blumenfeld-Kosinski-Timea Szell. Ithaca-London 1991. 199-221; Klaniczay Gábor: Az uralkodók szentsége a középkorban. Bp., 2000. 195-209.

37 Teleki-kódex. 295/36-296/5.

38 Uo. 296/7-16. 
Az Annából származtatott geneaológiát, Jézus családfáját gyakran Arbor Anna fructuosa névvel illetik legendákban, amint azt Ton Brandenbarg késő középkori, német nyelvterületen terjedő legendákon végzett kutatása mutatja. ${ }^{39}$ Ebben az esetben a három szőlővessző, ami a három Máriát jelenti, eucharisztikus szimbólum, és egyben utal Jézus földi családjának a küldetésére, az apostolok térítő tevékenységére, amit az emberiség üdvéért vállalnak fel.

\section{A KAZINCZY-KÓDEX ANNA-LEGENDÁJA}

A kódex nagy valószínűséggel az óbudai klarisszák számára készült, egyetlen kéz munkája (feltehetően Lippai Ferencé), 1526 és 1541 között íródott. ${ }^{40}$

Akárcsak a Teleki-kódex Anna-legendája, a Kazinczy-kódexben külön fejezet szól Emerentia történetéről. Majd Anna és Joachim szentéletű házasságát mutatja be a kódex másolója. Elmarad azonban az Anna három házasságáról szóló történet ismertetése. ${ }^{41}$

A Kazinczy-kódex tartalmát tekintve bővelkedik tanító szándékú, ugyanakkor fordulatos olvasmányokban - prédikációk, legendák (Szent Elek, Szent Anna, Szent Orsolya és a tizenegyezer szúz, Antiochiai Szent Margit legendája) - nagyrészt a Mária-tisztelet jegyében készültek (Mária haláláról, A jegyesét Szüz Máriáért elhagyó magyar királyfi története, Mária nevének betüiröl, Szent Anna legendája.), ill. A jegyesét Szüz Máriáért elhagyó magyar királyfi története a szeplőtelen fogantatás ünnepéhez kötődő történet. ${ }^{42}$

Mind tartalmi vonatkozásban, mind a kódex célközönségét (klarisszáknak íródott) tekintve, a kódex ferences másolója valószínűleg nem találta megfelelőnek, hogy beemelje Anna három házasságának vitatott történetét.

\section{AZ ÉRDY-KÓDEX ANNA-LEGENDÁJA}

Filológiai kutatások még nem tisztázták az Érdy-kódex Anna-legendájára nézve a forráshasználatot. Az Érdy-kódex írója (Lövöld, 1526), ${ }^{43}$ a Karthauzi Névtelen, az Arany Legendát, ill. Temesvári Pelbárt Anna-prédikációját is felhasználhatta forrásként. ${ }^{44}$

39 Ton Brandenbarg: Saint Anne, 41.

40 Kovács Zsuzsa: F. Fráter munkái: a Kazinczy-kódex és a Tihanyi-kódex. Magyar Nyelv, szeptember (2002). 364-380.

41 Kazinczy-kódex. 39-58.

42 DÁm Ince: A szeplötelen fogantatás védelme Magyarországon a Hunyadiak és Jagellok korában. Róma 1955. 58-61.

43 A szakirodalomban vita folyik arról, hogy a kódex egy vagy két kéz másolata. Lévén, hogy minimális a különbség a két típusú írásmód között, BAKonYI Dóra és LudánYi Brigitta arra a következtetésre jutottak, hogy feltehetően egy kéz munkája. Lásd BAкоNYI Dóra, LudÁNYi Brigitta: $A z$ Érdykódex feltételezett két kezének és a Jordánszky-kódexnek összehasonlitó vizsgálata a sorvégi elválasztás alapján. Plaustrum seculi II(2004). http://sermones.elte.hu/?az=320tan_plaus_dorabrigi (letöltve 2009.04.30).

44 Iacopo Da Varazze. Legenda Aurea. 2 kötet. 900-917; Pelbartus, Pomerium de sanctis 36, 37, 38 sermok. A szerző által használt irodalmi forrásokra nézve lásd Horváth: A magyar irodalmi múvelt- 
Jóllehet mind az Arany Legendában, mind Pelbárt prédikációjában jelen van a trinubium legenda, a Karthauzi Névtelen kihagyja e történetet az Anna-legenda bemutatásakor, megemlíti viszont Anna „szentséges magzatit”: a három Máriát és a nyolc apostolt. A következőképpen zárja fejtegetését: „Ha azért dicseködni akar Szent Anna asszon ő nemzetségéből igazán teheti és bűnnélkül”. ${ }^{45}$

Mi lehet a magyarázata annak, hogy a Karthauzi Névtelen, jóllehet szót ejt a Nagy Szent Családról, nem említi Anna három házasságát? Ha az Érdy-kódex tartalmát vesszük figyelembe, feltűnik, hogy a szerző a szeplőtelen fogantatás tana mellett foglal állást legendagyüjteményében: két prédikációt is szánt a szeplőtelen fogantatás ünnepének, illetve részletesen kifejti, miért kell Mária szeplőtelenségét ünnepelni, és panaszkodik amiatt, hogy a bázeli zsinat e tanra vonatkozó határozatai nem léptek érvénybe. ${ }^{46}$ Továbbá az Anna-legenda bemutatásakor többszörösen Anna és Joachim szent házasságát emeli ki. ${ }^{47}$

Feltehetően a szerző a szeplőtelen fogantatás tana mellett foglalva állást, érdemesnek látta, hogy kihagyja a vitatott trinubium legendát. Nem hagyta figyelmen kívül azonban, hogy a késő középkori devóció része volt Jézus tágabb földi családja, s így, különösebb magyarázat nélkül, csupán utalásképpen, beemelte az Anna-legendába, lévén, hogy legendagyưjteményét eleve egy tágabb közönségnek szánta. ${ }^{48}$

\section{„CSODATÁR”: A TELEKI-KÓDEX LEGENDÁJÁNAK ANNA-CSODÁI}

A szent élettörténetének bemutatása mellett, a legendák részét képezik általában a szentről szóló csodák és imádságok. A csodák további információval szolgálhatnak a szent kultuszára

ség kezdetei.248; Bán Imre: A Karthauzi Névtelen múveltsége. Budapest 1976; Madas: A Néma Barát megszólal. 553-554; MADAs Edit: La Légende dorée - Historica Lombardica - en Hongrie = Spiritualità e lettere nella cultura italiana e ungherese del basso medioevo. Szerk. Sante GraciotTiCesare VASOLI. Florence 1945. 53-61; BÁrczi Ildikó: Ars compilandi: A késő középkori prédikációs segédkönyv forráshasználata. Budapest 2007. 39-40; Lásd még ezenkívül NAGY Emőke: Anyaság és szentség: Szent Anna és Szent Erzsébet Temesvári Pelbárt prédikációiban = Arpád-házi Szent Erzsébet: Magyar-német kultúrkapcsolatok Kelet-Közép-Európában. Szerk. Gáвor Csilla-Knecht TamásTAR Gabriella-Nóra. Kolozsvár 2009. 32-47.

45 Érdy codex. 148/35-36.

46 A szeplőtelen fogantatás tanát elfogadta a bázeli zsinat 1438-ban. Utólag azonban a zsinat határozatait érvénytelennek minősítette a pápa, lévén, hogy az egyház részéről a zsinaton részt vevők kisebbségben voltak. A ferences rendből származó IV. Sixtus elrendelte az offíciumok megírását a szeplőtelen fogantatás ünnepek megülésére, ami az ünnep félhivatalos elfogadását eredményezte. Wenceslaus Sebastian: The Controversy over the Immaculate Conception from after Scotus to the End of the Eighteenth Century = The Dogma of the Immaculate Conception. Szerk. O'Connor. 228-238; Cornelius A. Bouman: The Immaculate Conception in the Liturgy = The Dogma of the Immaculate Conception. Szerk. O'connor. 148-151.

47 Érdy codex. 144-150.

48 A kódex prológusában megfogalmazott írói szándék szerint a kódex azon különböző rendből származó laikus testvéreket és apácákat szeretné segíteni, akik nem tudnak latinul. Érdy-kódex, XXIIIXXIV; A Néma Barát megszólal. Válogatás a Karthauzi Névtelen beszédeiböl. Szerk. MADAs Edit. Bp 1985. 11-12. 
nézve. Csodák tekintetében a Teleki-kódex Anna-legendája a legbeszédesebb forrás. A Kazinczy-kódex másolója a Teleki-kódex „csodátárából” csupán egy történetet emel be (a tékozló fiú történetét $\left.{ }^{49}\right)$. Az Érdy-kódexből teljességgel elmarad a csodák bemutatása. ${ }^{50}$

Ton Brandenbarg már említett tanulmánya szerint a német nyelvterületen született Anna-legendák társadalomtörténeti megközelítésű elemzéséből kiderül: Anna a házasok védőszentje, az anyaság és termékenység szimbóluma, a városi középréteget szólítja meg, a róla szóló csodák alapján. ${ }^{51}$

A Teleki-kódexben elmesélt csodáknak ${ }^{52}$ különböző státusú főszereplője van (özvegy, apáca, remete, pap, püspök és egy női szent), anyaságra és termékenységre csupán egy csoda erejéig utal (Procopius magyar nemesember deák fiának története), ami arra enged következtetni, hogy a csodákat aszerint válogatták, hogy apácák vagy beginák olvassák majd azokat.

A Procopiusszal megtörtént csoda (IX. fejezet ${ }^{53}$ ), ami Európa-szerte jól ismert volt ${ }^{54}$, egy magyar deák történetét mutatja be. A nemes ember fiát, Procopiust egy gazdag várnagy (porkoláb) meg akarta győzni arról, hogy elvegye a nagyobbik lányát. Procopiust megigézte a lány szépsége, és hagyta magát rábeszélni. Közben azonban a jegyese meghalt. A várnagy felajánlja neki kisebbik lánya kezét. Azonban ő is meghal. Procopius bánatában úgy dönt remetének megy. A remetének megjelenik Anna látomásában nagyszámú leszármazottjával egy fa képében.

Jóllehet, amint már az előbbiekben említettem, himnuszokban, ill. legendákban az Annától származtatott genealógiát gyakran Arbor Anna fructuosa ${ }^{55}$ megnevezéssel illetik, ami egyértelmúen a fertilitásra utal, ebben az esetben a fa oltalmat nyújt a remetének. Oltalomról van szó spirituális értelemben, Anna és leszármazottai védelmét élvezheti kiszámíthatatlan útján a remete, és fizikai értelemben a fa megvédi őt a rossz időjárástól és éhségtől:

„...néminemű fáról almát láta, mely őtet megoltalmazandó volna, az esőtül, széltül, hidegtül, és heségtül, és az éhözőt, megelégítenéje az ő kedves gyömölcsével, bizonába mely fa miképpen követközik, e boldog szent Anna asszont példázza vala...". ${ }^{56}$

49 Teleki-kódex. 306-314; Kazinczy-kódex. 39-58.

50 Érdy-kódex. 144-150.

51 Brandenbarg: Saint Anne. 54; A csodák értelmezéséhez lásd Benedicta Ward: Miracles and the Medieval Mind: Theory, Record and Event 1000-1215. Philadelphia 1987; Michael E. Goodich: Miracles and Wonders: The Development of the Concept of Miracle, 1150-1350. Aldershot 2007; Klaniczay Gábor: The Construction of the Miracles of Saints in the Age of Medieval Canonization Processes. Előadás, elhangzott a Max Planck Történelemtudományi Intézet által megrendezett konferencia keretében (Miracles as Epistemic Things). Berlin, 2005. november 1-34.

52 Teleki-kódex. 298-324.

53 Uo. 301-306.

54 Petrus Dorlandus: Alter juvenis Hungarus à Sancta Anna plurimis beneficiis affectus = Acta Sanctorum quotquot toto orbe coluntur (a továbbiakban AASS). 68 kötet. Antwerp, Brussels 1643-1940. 5 kötet. Január. 264-265.

55 Brandenbarg: Saint Anne, 41.

56 Teleki-kódex. 302/27-31. 
Valószínúleg nem véletlen, hogy a Procopiust védelmező fa almafa. A legenda írója e szimbólumon keresztül is arra utalhatott, hogy csak Jézuson és az ő Annától, nagyanyjától származó rokoni körének tiszteletén keresztül vezethet a megváltás útja. Procopiusszal megtörtént csodatörténetnek több helyszíne és állomása van remeteélete során. Egyike ezeknek az a momentum, amikor Anna segíti őt abban, hogy megtalálja a gazdagságot. Procopius hálája jeleként kéri az ország királyát, hogy verethessen érméket Annát ábrázolandó harmadmagával. A csodatörténet egy másik része fertilitáshoz kötődik. Ugyanazon ország királynéja várandós. Anna jelenik meg neki és megkönnyíti szülését. Imáját az Anna harmadmagával érmére veretett kép inspirálja, amit a király adott neki ajándékba:

„...az első pénzt, szent Anna asszonnak szeretetiért, a királyné asszonnak adom, az én házas társomnak, hogy nyakára kösse, hogy avagy csak az ő képének tekentetiből, megszabadulhasson a szülésnek menden keserűségétül...”. ${ }^{57}$

A szimbólummal ellátott érme jelzésértékű az Anna harmadmagával képek és az ezzel kapcsolatos imák szoros összefüggésére nézve:

„...asszonyállatoknak jelen voltoknak, vigasztalásoknak, keserűségőkbe és veszödelmekbe helhöztetvén, Istennek akaratjából, kezde gondolkodni a bodog szent Anna asszonnak segédségéről, és meglátván a pénzt az ő nyakában, a szent Anna asszonnak képével, nagy óhajtással és alázatos csókolással mondá: ó szentségős anya Anna asszon, mastan énnéköm légy segédség harmad magaddal..." 58

Legtöbb csoda különböző történetek keretében, Anna három házasságával kapcsolatosan arról győzi meg a kételkedô apácákat, hogy az üdvözüléshez Anna tiszteletén keresztül vezet az út.

A késő középkori magyar kódexirodalom egyik kedvelt női szentje svédországi Szent Brigitta. Az ő Szent Annával megtörtént látomását megtaláljuk a Teleki-kódex Anna-legendájában (XII. fejezet)..$^{59}$

A Teleki-kódexből kimarad a látomás történeti kerete. E történet szerint Szent Anna akkor jelent meg Brigittának, amikor ő római zarándoklaton vett részt, abból a célból, hogy Anna-ereklyéket szerezzen. ${ }^{60}$ Brigittának imádkozás közben jelenik meg Anna és arra buzdítja őt, hogy a házasságban élőkért a következőképpen imádkozzon: „...kérlek alázatossággal, azoknak, és mendenöknek érdömökért, méltoltassál irgalmaznod a házasoknak, a te

57 Teleki-kódex. 303/30-33.

58 Uo. 304/2-8.

59 Uo.316-317.

60 Birgitta Of Sweden: The Liber Celestis of St. Bridget of Sweden. Szerk. Roger Ellis. Oxford, 1987 (Early English Text Society 1 kötet). 467; Svédországi Szent BRIGiTTA életére nézve lásd Günther Schiwy: Birgitta von Schweden: Mystikerin und Visionärin des späten Mittelalters, eine Biographie. München, 2003. 
parancsolatid erízőkkel, jelesben azokkal, kik a te szüleidnek szolgálatjába, és tiszteletibe állnak....". ${ }^{61}$

Szent Anna úgy mutatkozik be tehát Brigittának, mint aki a házasságban élőknek a védőszentje:

„én édes szerető leányom, én vagyok a szent Anna asszon, istennek szülejének, az édes szíz Máriának anyja, és a mendenható istennek fiának üki, emberi nemzetnek kiváltkepen való szerzet oltalma, és segédsége, demaga jelesben házasságban élőknek, és istennek félelmet vallóknak... és az én tisztességömet el ne feleged, de engömet gyakorlatos üdvözlettel kerges, és egyebeket és erre taníts, mel tanúságot, és imádságot, tenéköd ítéltem megjelöntenöm" ${ }^{62}$

Brigitta legendái alapján már házasként kegyes életet élt, önmegtartóztatásban, imával, munkával töltve napjait, ill. férjével, Ulf Gudmarrsonnal együtt kórházat alapított a szegények megsegítésére. Ugyan nyolc gyermek születtett házasságukból, elhivatottságukat jelzi, hogy mindketten beléptek a ferences harmadrendbe, illetve tisztasági fogadalmat tettek idősebb korukban. Férje halála után Brigitta elzarándokolt Rómába, ekkor jelenik meg látomásában Szent Anna. A megözvegyült, többgyermekes anya férje halála után lemondott a földi örömökről és Krisztus követője lett (megalapítja a róla elnevezett rendet). Anna, mint több ízben férjezett, de kegyes életvitelű asszony, példaképül szolgált a megözvegyült, szent életet választó Brigittának. ${ }^{63} \mathrm{~A}$ történet nagyon jól példázza a szentek legendáinak hatását a korabeli társadalomra: Brigitta legendája a maga során ugyanúgy hatott hasonló élethelyzetű nőkre, mint például az úgyszintén többgyerekes, megözvegyült Margery Kempere. ${ }^{64}$

Továbbá számos csoda kötődik Annának veszélyes élethelyzetekben való segítségéhez: hajótörés, betegség esetén, ill. haldoklók fohászkodnak hozzá. E történetek főszereplői az egyházi társadalom különböző szintjét képviselik: remete, pap, apáca (XIII-XVII. fejezetek). ${ }^{65}$

Két történet, egy püspökkel és egy apácával megtörtént esemény elrettentő példaként szerepel a kódexben arra nézve, milyen iszonyatos haragot hív ki maga ellen az, aki elveti Anna tiszteletét (XI., XVII. fejezet). ${ }^{66}$ E történetek arra hivatottak, hogy egyházi környezetben erősítsék meg Anna kultuszát, olyan réteg számára íródtak, akik nehezen fogadták el: anyaság és szentség összeegyztethető.

A szent halál fölötti hatalma, ill. a hozzá fohászkodók segítését hivatott példázni egy, úgyszintén apácával megtörtént csoda. Colettának álmában megjelenik Anna, és felmutatja neki

61 Teleki-kódex. 317/1-4.

62 Uo. 316/23-31.

63 The Liber Celestis. 1-6; Elliot: Spiritual Marriage. 226.

64 The Book of Margery Kempe. Ford. B. A. Windeatt. London 1985. 17; Elliott: Spiritual Marriage. 207.

65 Teleki-kódex. 317-325; 326/25-327/6.

66 Uo. 314-315; 327/16-327/38. 
hite jutalmát kezében: a paradicsom kapuját. A Teleki-kódex másolója kihagyja a híres apáca nevét, mintegy csak a történetet mesélve el röviden. ${ }^{67}$

A Teleki-kódex Anna-legendája didaktikai útmutatást is tartalmaz a csodákba szőtt imák révén. Legendája alapján Anna kedden született, kedden szülte Szűz Máriát, és kedden halt meg, emiatt e napon kell hozzá imádkozni, három Pater Noster és három Ave Maria elmondásával. Legtöbb csoda kiemeli, hogy imádkozás közben nem csupán Annának, hanem Máriának és Jézusnak is gyertyát kell gyújtani (lehetőség szerint Annát harmadmagával ábrázoló kép előtt), mert csak így talál meghallgatásra a fohász. ${ }^{68}$

Az Anna-kultusz ezen imák alapján szorosan kötődik a Mária és Jézus tiszteletéhez. Az Ave Maria-indíttatású Anna-imák a Mária-kultusszal való egybefonódását, ezzel párhuzamosan történő alakulását jelzik.

A három Anna-életrajz összehasonlításából kiderül, hogy mindhárom kódex Anna-legendája tükrözi a kultuszhoz kötődő ideológiai vitákat. A Teleki-kódex igen gazdag anyaga arra enged következtetni, hogy kolostori környezetben Annának a megváltásban betöltött közbenjáró szerepe emelődik ki mint legfőbb attribútum. A Kazinczy-kódex és Érdy-kódex írója pedig teljességgel mellőzi Szent Anna kultuszának vitatható elemeit, lévén, hogy írásukban a szeplőtelen fogantatás tana mellett foglalnak állást. Anna mint a jó feleség mintaképe jelenik meg e két kódexben, a Joachimmal kötött házassága révén. Csodák majdnem teljes hiánya miatt további következtetés nem vonható le ez utóbbi kódexek esetében.

\section{THE CHARACTERISTICS OF THE CULT OF ANA IN THE TELEKI, KAZINCZY AND ÉRDY CODICES}

\section{Keywords: cult, codices, St. Anne devotion, philology, anthropology legend, franciscan}

The veneration of St. Anne was far from being uncontroversial in the Middle Ages, due to her apocryphal origin, based on her vitae, and the theological debates regarding the conception of her daughter, the Virgin Mary. The surviving textual sources of her cult from late medieval Hungary are mostly sermons and legends written in Franciscan environments. The few existing studies on the written sources of St. Anne's cult in medieval Hungary surveyed only her legends preserved in manuscripts of Hungarian provenance. The earliest Anne legends in the Teleki and Kazinczy codices were written in Franciscan environment for the use of Tertiaries and Clarisse sisters. St Anne's legend in the Carthausian Érdy codex was intended to be read by a larger audience, namely nuns and lay brothers. In my paper I examine these works in the broader context of theological debates around Saint Anne's figure, and

67 A lipcsei 1497-es kiadásban sem szerepel ColETTA neve. A történetből azonban felismerhető annak főszereplője. Lásd Teleki-kódex. 316/1-20; Anonymus Ferences, Legenda sanctissime. http:// tudigit.ulb.tudarmstadt.de/show/show.inc-ii-236/0038 (letöltve 2011.05.11). Coletta életrajzát megírta Peter Of Vaux: Vita sanctae Colettae = AASS. Március. 1 kötet. § 68. Coletta életének feldolgozását lásd Elisabeth Lopez: Culture et sainteté: Colette de Corbie, 1381-1447. Saint Étienne 1994. Coletta Anna látomásának értelmezését lásd Kathleen Ashley: Image and Ideology: Saint Anne in Late Medieval Drama and Narrative = Interpreting Cultural Symbols. 111-131, 119, 127; Ashley-Sheingorn: Introduction. 35.

68 Vö. Teleki-kódex. 319-325. 
focus on the manners scribes presented the saint's vita in ecclesiastical environment. The anthropological approach to Anne's legends allows us to contextualize the saint's cult; to identify the main ideas about the saint's cult, her most important attributes, transmitted by the scribes to the targeted segment of society. The philological analyzes carried out by Lajos Katona, János Horváth, and Anna Veres aimed to trace the sources of Anne's legends in the three Hungarian codices. Nevertheless, they did not analyze these texts by taking into consideration the intended readers, and by contextualizing them in the late medieval sainthood. The latter analytic approach was not developed until now.

\section{TRĂSĂTURILE CULTULUI SFINTEI ANA PE BAZA CODICELOR TELEKI, KAZINCZY ŞI ÉRDY}

\section{Cuvinte-cheie: cult, devoțiune, filologie, antropologie, Sfânta Ana, legendă, franciscan}

Cultul Sfintei Anna a fost controversat în cursul Evului Mediu pe de o parte datorită originii sale apocrife, bazat pe legendele sale, pe de altă parte datorită dezbaterilor teologice în legătură cu Imaculata Concepție care au inclus-o și pe mama Fecioarei. Sursele medievale literare eclesiastice (legende, predici) provin din mediu franciscan în cele mai multe cazuri. Cele mai timpurii surse literare, legendele Sfintei din codicele Teleki respectiv Kazinczy, au fost scrise în mediu franciscan în folosul terțiarelor și clariselor. Legenda Sfintei din codicele Érdy a fost menită să fie citită de o audiență mai mare (călugărițe etc). În prezenta lucrare analizez legendele Sfintei Ana din cele trei codici amintite luând în considerare dezbaterile teologice în legătură cu dogma Imaculatei Concepții, respectiv luând în considerare felul în care legenda este prezentată într-un context eclesiastic. Dezbaterea antropologică ne îngăduie să vedem cultul sfintei într-un spectru mai larg, cea a devoțiunii medievale târzii (a identifica ideile, caracteristicile principale ale cultului Sfintei) - idee care nu a fost dezbătută încă. Analizele filologice ale lui Lajos Katona, János Horváth și Anna Veres au avut ca scop identificare sursei legendelor din cele trei codici. Autorii amintiți nu au luat însă în considerare în analiza lor aspectele amintite mai sus. 